\title{
LEGISLATIVE QUALITY AND THE SCOTTISH PARLIAMENT
}

\section{A. INTRODUCTION}

Writing in The Scotsman in July 2016, Alistair Bonnington made the startling claim that the Scottish Parliament produces "the lowest quality legislation in Europe." ${ }^{1}$ Such hyperbole is easy to dismiss; given the linguistic challenges, and the varying roles and styles of legislation in different legal systems, how would one even begin to make such a comparative assessment? Nevertheless, complaints about the rigour of Holyrood's legislative process and the quality of its legislative output, usually by comparison with Westminster, have dogged the Parliament since its earliest days, though criticisms are more often based on assertion and anecdote than detailed analysis. This is perhaps unsurprising given that measuring the quality of legislation and the effectiveness of parliamentary scrutiny are more complex tasks than might be thought. ${ }^{2}$ This note aims to shed some light on the debate by considering the different things we might mean when talking about "good" or "bad" legislation and by identifying what we know - and, more importantly, what we do not know - about Holyrood's performance measured against these criteria.

\section{B. SUBSTANTIVE QUALITY}

Complaints about poor quality legislation often concern the substantive merits of particular Acts. Critics may believe that the aims are objectionable, the methods chosen to achieve those aims are misguided, or the policy could have been implemented without requiring new legislation. Such judgments are necessarily subjective, and the quality of Holyrood's legislative output cannot be condemned merely because some disagree with it. However, more meaningful assessments of substantive quality can be made in terms of democratic legitimacy and policy effectiveness. In other words, is Holyrood legislation responsive to the needs and wishes of people in Scotland, and does it achieve its aims without creating unanticipated problems?

\section{(1) Democratic Legitimacy}

A - perhaps the - key function of a Westminster-style parliament is to confer democratic legitimacy on legislative proposals. ${ }^{3}$ Since the legislative initiative in such systems rests primarily with the executive, the main function of the parliamentary process is "to turn something politically contentious into something that attracts greater public acceptance and adherence." ${ }^{4}$ Given Holyrood's popularity, ${ }^{5}$ it cannot plausibly be argued that it does not do this successfully ${ }^{6}$ - certainly much better than the situation before devolution. The lack of time for Scottish legislation at Westminster, and the perceived democratic deficit arising from divergent electoral majorities at

\footnotetext{
1 "One Party State is the Enemy of Democracy", The Scotsman, 21 July 2016.

2 See Sir Stephen Laws, "What is the Parliamentary Scrutiny of Legislation For?", in A Horne and A Le Sueur (eds), Parliament Legislation and Accountability (Hart Publishing Ltd, Oxford, 2016) $16-17$.

3 lbid, at 27.

${ }^{4}$ Ibid.

${ }^{5}$ See ScotCen, Scottish Social Attitudes Survey 2015, Attitudes to the Role of the Scottish Parliament: Data Tables (2016), available at: http://www.ssa.natcen.ac.uk/media/38893/ssa15-tables-for-web.pdf.

${ }^{6}$ See, eg, Commission on Scottish Devolution, Serving Scotland Better: Scotland and the United Kingdom in the $21^{\text {st }}$ Century (2009) 58; J Mitchell, "The Narcissism of Small Differences: Scotland and Westminster" (2010) 63 Parliamentary Affairs 98 at 113; P Cairney and J Johnston, "What is the Role of the Scottish Parliament?" (2013/14) 1 Scottish Parliamentary Review 91 at 130.
} 
Scottish and UK levels were both key arguments for devolution. The mere existence of the Parliament, along with its more proportional electoral system, means that it is much more democratically responsive, passing far more, and more timely legislation, better tailored to Scottish circumstances and political priorities

Of course, the process is not perfect. As in any Westminster system, Holyrood's legislative process is highly executive-dominated. Aspirations - perhaps naïve - for greater power-sharing between the Parliament and executive than at Westminster ${ }^{7}$ have not been realised. ${ }^{8}$ But there is far more extensive public engagement in the legislative process through the committee system, particularly at Stage $1,{ }^{9}$ even if more could be done to encourage wider participation, and at later stages. ${ }^{10}$ Committees are often criticised for lack of political independence. ${ }^{11}$ But suggestions that Holyrood needs a second chamber to bring a degree of independent scrutiny to the legislative process ${ }^{12}$ have their own problems. An unelected second chamber would undermine the democratic legitimacy of Scottish legislation, whereas an elected second chamber would be less independent of party politics and it is unclear what democratic value it would add.

(2) Policy Effectiveness

Legislation may be democratically legitimate, yet poor quality because it proves to be ineffective. A second aim of the legislative process is therefore to scrutinise the policies embodied in legislation and amend them where necessary.

There has been no comprehensive analysis of the extent to which the Scottish Parliament influences the content of legislation. While there are greater opportunities than at Westminster for MSPs, and also Committees, to propose legislation, Scottish Government business dominates proceedings, ${ }^{13}$ and it rarely suffers defeats. Although formal defeats are a poor measure of parliamentary influence, ${ }^{14}$ and parliamentary pressure clearly does sometimes make a difference, it nevertheless seems likely that Holyrood's policy influence is relatively limited. Parliamentary involvement comes late in the policy-making process, only once a Bill has been introduced. There is no regular prelegislative scrutiny of draft Bills. Nor is there any systematic post-legislative scrutiny to assess whether legislative aims are being met.

\footnotetext{
${ }^{7}$ See B Crick and D Miller, To Make the Parliament of Scotland a Model for Democracy (John Wheatley Centre, 1995); Consultative Steering Group, Shaping Scotland's Parliament (Scottish Office, 1998).

${ }^{8}$ On the essential similarity of the Scottish and UK Parliaments, see Mitchell, above n6; Cairney and Johnston, above n6.

${ }^{9}$ See J Johnston, "The Legislative Process: the Parliament in Practice", in C Jeffery and J Mitchell (eds), The Scottish Parliament 1999 - 2009: the First Decade (Hansard Society/Luath Press Ltd, Edinburgh, 2009).

${ }^{10}$ See Cairney and Johnston, above n6, at $113-5$; Scottish Parliament Standards, Procedures and Public Appointments Committee (SPPAC), Legislation and the Scottish Parliament, $3^{\text {rd }}$ Report 2015 (Session 4) SP Paper 697.

${ }^{11}$ See C Carman and M Shephard, "Committees in the Scottish Parliament", in Jeffery and Mitchell, above n9; Cairney and Johnston, above n6, at $118-119$.

${ }^{12}$ See Lord Hope of Craighead, "What a Second Chamber Can Do for Legislative Scrutiny" (2004) 25 Stat LR 3; HL MacQueen, "A Second Chamber for the Scottish Parliament?" (David Hume Institute, Revised edn, 2015).

13 A Page, Constitutional Law of Scotland (W Green \& Son, Edinburgh, 2015) paras 13.02, 13.29 -13.32.

${ }^{14}$ See D Gover and M Russell, "Parliament and Legislation: Perhaps Westminster is More Powerful Than You Think?", The Constitution Unit, 15 September 2015, available at: https://constitutionunit.com/2015/09/15/parliament-and-legislation-perhaps-westminster-is-more-powerful-than-youthink/\#more-4156.
} 
One apparent problem is the small size of the Parliament. Committees are seen as being overburdened - something likely to be exacerbated by Holyrood's recently increased responsibilities. The legislative process is also sometimes perceived to be rushed; although in theory, the Parliament has the whole four/five yearly session in which to enact legislation, there is a political imperative to complete the process within an annual cycle. ${ }^{15}$ And there have been persistent problems with turnover of committee members, reducing their ability to develop policy expertise. ${ }^{16}$ Steps have been taken to try to address some of these issues. ${ }^{17}$ However, Cairney suggests that they are endemic to a Westminster-style legislature, in which there is an inevitable imbalance in the resources available to government to produce policy and to the Parliament to scrutinise it. ${ }^{18}$

Despite these weaknesses, there is no evidence of systemic legislative failure. The most comprehensive study of Holyrood's legislative output to date painted a predictably mixed picture, with greater perceived success in some areas than others. ${ }^{19}$ An equivalent review of Westminster's legislative output would almost certainly produce a similar level of criticism. ${ }^{20}$ Indeed, the House of Commons Political and Constitutional Reform Committee in a 2013 report noted repeated criticisms about the quality of legislation, and that witnesses had been unanimous in calling for improved legislative standards. ${ }^{21}$ Moreover, where there have been policy failures (and those failures were predictable or avoidable), it is difficult to know how much of the blame should be placed on the Parliament. ${ }^{22}$ Since determining legislative policy is primarily a matter for government, conducted in consultation with policy networks, legislative failures may indicate weaknesses in policy capacity (in government and/or civil society) rather than in the legislative process. Alternatively, problems my lie not with the legislation itself, but instead with its implementation - lack of funding, inadequate training, IT problems, etc.

\section{CONSTITUTIONAL QUALITY}

As a legally-limited legislature, what might be termed "constitutional quality" is a particularly important issue for the Scottish Parliament. Acts of the Scottish Parliament (ASPs) which breach the limits in section 29 of the Scotland Act 1998 - most significantly, if they relate to reserved matters or are incompatible with Convention rights or European Union law - are "not law" and risk being struck down by the courts. Express vires constraints do not exhaust considerations of constitutional quality, however. There may also be concerns about legislation which, for instance, contains excessive delegations of legislative power, has retrospective effects, interferes with the separation of powers, and so on. ${ }^{23}$ Breach of constitutional standards does not necessarily make legislation bad

\footnotetext{
${ }^{15}$ Page, above $\mathrm{n} 13$, at paras $13.07-13.09$.

${ }^{16}$ See Carman and Shepherd, above n11.

${ }^{17}$ The SPPAC has issued several recent reports recommending improvements in legislative and committee procedures - Post-Legislative Scrutiny, $8^{\text {th }}$ Report 2013 (Session 4), SP Paper 410; Legislation and the Scottish Parliament, above n9; Committee Reform, $1^{\text {st }}$ Report 2016 (Session 4), SP Paper 882.

18 SPPAC, above $\mathrm{n} 11$, annexe $\mathrm{C}$.

${ }^{19}$ E Sutherland et al (eds), Law-Making and the Scottish Parliament: the Early Years (Edinburgh University Press, 2011).

${ }^{20}$ For a depressing litany of UK Government policy failures, see A King and I Crewe, The Blunders of Our Governments (One World Publications, 2013).

${ }^{21}$ Ensuring Standards in the Quality of Legislation, $1^{\text {st }}$ Report $2013-14$, HC 85, 5, 7.

${ }^{22}$ Cf Laws, above n2, at 7.

${ }^{23}$ See J Simson Caird, R Hazell and D Oliver, The Constitutional Standards of the House of Lords Select Committee on the Constitution (The Constitution Unit, $2^{\text {nd }}$ edn, 2015).
} 
in a substantive sense. An ASP which is,say, ultra vires for encroaching on reserved matters may be unobjectionable if enacted by Westminster. In other cases, though, assessments of constitutional quality shade into assessments of substantive merits and may be equally contestable.

In recent years, the UK Parliament has become more concerned with policing the constitutional quality of legislation, via the House of Lords' Constitution Committee and Delegated Powers and Regulatory Reform Committee, and the Joint Committee on Human Rights. ${ }^{24}$ In the Scottish Parliament, the Delegated Powers and Law Reform Committee examines proposed delegated powers, but there is no committee specifically charged with assessing the vires of Bills, nor compliance with broader constitutional standards. ${ }^{25}$ Instead, Holyrood relies on the statutory machinery of ministerial/Presiding Officer statements as to competence, and the Law Officers' powers to refer Bills to the Supreme Court ${ }^{26}$ to ensure scrutiny of constitutional quality - a process which is narrowly focused on questions of vires, and is conducted almost entirely by negotiation behind closed doors, ${ }^{27}$ with MSPs being given little information on which they might form their own conclusions. ${ }^{28}$

That said, the system appears to work effectively. There have only ever been three successful competence challenges to ASPs, all on human rights grounds. ${ }^{29}$ By comparison, ${ }^{30}$ nine UK statutes enacted since 1999 have been declared incompatible with Convention rights. ${ }^{31}$ This is, however, only a partial indicator of constitutional quality. No figures are available on how often judges have given legislation a strained interpretation ${ }^{32}$ in order to avoiding condemning it. Nor is it possible to determine whether potential challenges have been missed. Similarly, as far as wider measures of constitutional quality are concerned, no systematic evaluation of Scottish legislation has yet been conducted. ${ }^{33}$

\section{TECHNICAL QUALITY}

A final set of criteria relates to the technical quality of legislation. According to the UK Parliamentary Counsel, good law should be: necessary; clear; coherent; effective; and accessible. ${ }^{34}$ Assessing the technical quality of legislation may appear to involve the least contentious judgments, but in reality

\footnotetext{
${ }^{24}$ See J Simson Caird and D Oliver, "Parliament's Constitutional Standards", in Horne and Le Sueur, above n2.

${ }^{25}$ Responsibility for the constitution has recently been added to the Finance Committee's remit, but it is not yet clear how this will be discharged.

${ }^{26}$ Scotland Act 1998, ss 31 and 33.

27 See A Page, "A Parliament that is Different? The Law-Making Process in the Scottish Parliament", in Sutherland et al, above $\mathrm{n} 19$, at $20-22,28-30$.

${ }^{28}$ No reasons are required for competence statements, except where the Presiding Officer considers that a Bill is ultra vires - Standing Orders of the Scottish Parliament $\left(5^{\text {th }}\right.$ edn, revision 1, 2016) Rule 9.3(1)(b).

${ }^{29}$ Cameron v Cottam 2012 SLT 173 (Criminal Justice and Licensing (Scotland) Act 2010, s 58); Salvesen v Riddell [2013] UKSC 32 (Agricultural Holdings (Scotland) Act 2003, s 72); Christian Institute v Lord Advocate [2016] UKSC 51 (Children and Young Persons (Scotland) Act 2014, Pt 4).

${ }^{30}$ The comparison is not direct, given Westminster's broader legislative responsibilities than Holyrood.

${ }^{31}$ Human Rights Act 1998, s 4.

32 Scotland Act 1998, s101; Human Rights Act 1998, s3.

${ }^{33}$ But see A O'Neill, "Human Rights and People and Society", in Sutherland et al, above n19, for criticism of Holyrood's record in protecting human rights.

${ }^{34}$ Office of Parliamentary Counsel, Good Law Initiative, https://www.gov.uk/guidance/good-law.
} 
some technical desiderata may be in tension with others, and legislation also has to serve different audiences (politicians, lawyers and judges, the public) with varying requirements. ${ }^{35}$

The Scottish Parliament has faced significant criticism of its performance as a technical scrutineer of legislation. MSPs are alleged to lack interest in, and aptitude for, the task. ${ }^{36}$ There are also fewer legislative stages than at Westminster, meaning that late amendments may not be properly scrutinised. ${ }^{37}$ To address the latter problem, recommendations have been made to move from a three-stage to a four-stage legislative process (splitting the last amendment stage and final approval of the Bill), as well as to increase minimum periods between stages and require earlier notification of amendments. ${ }^{38}$ Again, though, some argue that effective technical scrutiny requires a second chamber, ${ }^{39}$ or at least by review by an independent panel of experts. ${ }^{40}$

Others, however, contend that it is not the Parliament's function to ensure the technical quality of legislation; rather the primary responsibility lies with government and drafters. ${ }^{41}$ The Scottish Parliamentary Counsel undoubtedly take that responsibility seriously. ${ }^{42}$ In fact, some criticisms of the technical quality of ASPs may be a reaction to deliberate differences in their drafting style compared with UK legislation. ${ }^{43}$ While particular instances of poor drafting can nevertheless be identified, it is once again unclear whether the error rate is greater than can reasonably be expected given the inherent difficulties involved in legislative drafting, or any greater than for UK statutes.

\section{E. CONCLUSION}

There are multiple criteria by which to judge good and bad legislation. While there may be cause for concern about Holyrood's performance against some of those criteria, we lack robust evidence about how well it discharges its legislative functions and, crucially, about how this affects the quality of its legislative output. It is clearly appropriate to seek to improve the legislative process where possible, but it is also important to be realistic about the standard to be reached, and about the Parliament's contribution to its achievement. Perfection is not attainable; and parliaments play only a limited part in the production of legislation. Accordingly, the case that Holyrood is a poor legislator is - for now at least - at best, not proven.

Aileen McHarg

University of Strathclyde

\footnotetext{
${ }^{35} \mathrm{Cf}$ Laws, above $\mathrm{n} 2$, at 30.

${ }^{36}$ Hope, above n12, at 8; J McCluskie, "New Approaches to UK Legislative Drafting: the View from

Scotland" (2004) 25 Stat LR 136 at 141.

${ }^{37}$ Calman, above n6, at 224- 6; SPPAC, above n10, at $14-24$.

38 Ibid.

${ }^{39}$ Hope, above n12; MacQueen, above n12.

${ }^{40}$ Lord Steel of Aikwood, "A Dozen Differences of Devolution", in Jeffery and Mitchell, above n9, at $20-21$.

${ }^{41}$ Laws, above n2, at 36; Cairney, above n18.

${ }^{42}$ See Parliamentary Counsel Office, Drafting Matters! (Scottish Government, 2016).

${ }^{43}$ See McCluskie, above n36.
} 